Discussion Paper No. 06-072

Does Accounting for Taxes on Income Provide Information about Tax Planning Performance?

- Evidence from German Multinationals

Michael Overesch and Ulrich Schreiber

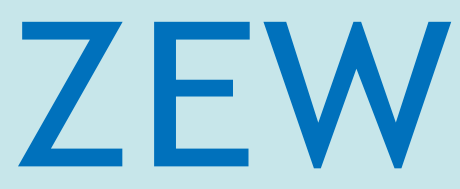

Zentrum für Europäische Wirtschaftsforschung $\mathrm{GmbH}$

Centre for European

Economic Research 


\title{
Discussion Paper No. 06-072 \\ Does Accounting for Taxes on Income Provide Information about Tax Planning Performance? - Evidence from German Multinationals
}

\author{
Michael Overesch and Ulrich Schreiber
}

Download this ZEW Discussion Paper from our ftp server:

ftp://ftp.zew.de/pub/zew-docs/dp/dp06072.pdf

Die Discussion Papers dienen einer möglichst schnellen Verbreitung von neueren Forschungsarbeiten des ZEW. Die Beiträge liegen in alleiniger Verantwortung der Autoren und stellen nicht notwendigerweise die Meinung des ZEW dar.

Discussion Papers are intended to make results of ZEW research promptly available to other economists in order to encourage discussion and suggestions for revisions. The authors are solely responsible for the contents which do not necessarily represent the opinion of the ZEW. 


\section{Non-Technical Summary}

The objective of IFRS financial statements is to provide useful information to decision makers. Accounting information about the company's tax burden is distorted by differences in the asset or liability tax base and its carrying amount in the balance sheet. Therefore, IAS 12 (Income Taxes) requires a company to recognise a deferred tax liability or a deferred tax asset. IAS 12 does neither permit nor require future tax payments to be discounted. On the other side, tax planning should focus on the net present value of the company's tax payments. Although timing effects of taxation are suppressed by reported tax expenses, it is common practice to use accounting information as a performance measure for the company's tax management.

A simple investment model of a multinational company shows that IAS 12 does not consider the effects of different depreciation rules on the net present value of an investment. Hence, it is very likely that the information about the tax consequences of investment decisions and international investment shifting is misleading. However, IAS 12 provides meaningful information if the company's tax planning is driven by the statutory tax rate as in the case of international profit shifting. Consequently, the information content of income tax accounting in accordance with IAS 12 depends on the relevance of the respective type of tax planning in which the company engages.

Using a panel of firm-level balance sheet data of German outbound FDI, provided by the Deutsche Bundesbank, we investigate empirically companies' tax planning patterns. We find empirical evidence that German multinationals engage in tax rate driven international profit shifting via debt financing and intra-firm sales. Thus, we conclude that insofar IAS 12 discloses the relevant information about the company's tax burden. However, we also find empirical evidence that tax depreciation impacts on the size of investments. Consequently, we cannot rule out the possibility that IAS 12 does not fully disclose the company's tax burden. Since the information content of IAS 12 income tax accounting depends on the 
relevance of the respective type of tax planning, both shareholders and the company's tax management should use accounting information provided by IAS 12 with caution. Reported effective tax rates might be seriously misleading, when the company's tax planning strategy focuses on real investments. 


\title{
Does Accounting for Taxes on Income Provide Information about Tax Planning Performance? - Evidence from German Multinationals $\ddagger$
}

\author{
Michael Overesch \\ $(\mathrm{ZEW})^{*}$ \\ Ulrich Schreiber \\ (Mannheim University and ZEW) **
}

October 2006

\begin{abstract}
This paper investigates the quality of information on tax planning performance which is provided by financial accounting based on IAS 12 (Income taxes). A simple theoretical investment model is used to show that reported tax expenses can be misleading as an indicator of tax planning performance, since timing effects of tax depreciations are suppressed. However, it is shown that IAS 12 provides meaningful information if tax planning strategies are driven by statutory tax rate differences, e.g. in the case of profit shifting. Our empirical analysis of actual tax planning behaviour, based on a panel of German balance sheet data, suggests that in practice international tax planning is significantly driven by statutory tax rates. However, we find that tax depreciation impacts on the size of investment as well and thus, IAS 12 does not fully disclose tax planning performance.
\end{abstract}

Keywords: International Taxation, Financial Accounting, Income Taxes, Firm-level Data

\footnotetext{
${ }^{\ddagger}$ We are grateful to the Deutsche Bundesbank for granting access to the MiDi database. Financial support by the German Research Foundation (DFG) is gratefully acknowledged.

${ }^{*}$ Centre for European Economic Research (ZEW), L 7,1, D-68163 Mannheim, Germany, overesch@zew.de, +49 621235394.

**Mannheim University, Schloss, D-68131 Mannheim, Germany, Ulrich.Schreiber@bwl.uni-mannheim.de, +4962181 1718 .
} 


\section{Introduction}

The International Financial Reporting Standards (IFRS) require a company to account for current and future tax consequences, due to transactions and other events recognised in profit or loss (IAS 12). Reported tax expense (tax income) seems to be relevant for both company tax management (Bolton, Chastel and Young, 2004) and shareholder investment decisions (Swenson, 1999, Scholes et al., 2005, 44-45). IAS 12 does not require future taxes to be discounted. In contrast, effective tax planning exploits timing effects and thus operates with discounted tax payments. Moreover, investment decisions are based on discounted cash flows after taxes. This leads to the conclusion that IAS 12 income tax reporting fails to provide full disclosure of the company's tax burden (Guenther and Sansing, 2000, Halperin and Sansing, 2006, Becker, Fuest and Spengel, 2006). Why, then, should both tax management and shareholders use reported tax expenses to assess the tax burden of the company?

There is empirical evidence for both the decision usefulness (Beaver and Dukes, 1972, Chaney and Jeter, 1994) and the value relevance of income tax reporting (Givoly and Hayn, 1992, Amir, Kirschleitner and Willard, 1997). Compared to a capital market approach (Barth, Beaver and Landsmann, 2001), we do not test if income tax accounting amounts have a significant relation with share prices. Our focus is on the company's tax planning patterns in order to assess the information content of IAS 12 income tax reporting. Since IAS income tax reporting fails to disclose timing effects, the quality of information about a company's tax planning performance provided by IAS 12 depends on the dominant tax driver. Therefore, it is analysed whether tax planning is driven by the tax base which gives rise to timing effects or by the statutory tax rates.

Financial statements according to IFRS are mostly prepared by multinationals. These companies are able to engage in international tax planning by either shifting profits or real investments to low tax countries. Investment decisions are sensitive to statutory 
tax rates as well as to tax bases (e.g. tax depreciation rules) and, hence, timing effects of taxes matter (Devereux and Griffith, 1998). In contrast, profit shifting is driven by differences in statutory tax rates only. Consequently, IAS 12 income tax reporting is not severely distorted by timing effects of taxes, if profit shifting is the company's dominant tax planning tool. In this case, IAS 12 provides clear-cut information about the effective tax burden to both tax management and shareholders. Given this observations, the issues to be addressed in this paper are: Is there empirical evidence for profit shifting by means of inter-company finance and inter-company sales, and if so, do we also find evidence for investment shifting?

The remainder of the paper is organised as follows. In section 2 we develop a simple model of international tax planning. In section 3 and 4 we present the data used and the empirical investigation approach. In section 5 we then discuss our empirical findings, while section 6 concludes.

\section{A Model of International Tax Planning}

\subsection{International Tax Planning and Investment Shifting}

We employ a cash flow model in the tradition of King (1977) and King and Fullerton (1984), in order to analyse an investment at location $i$ in $t=0$ of the amount $k_{i}$ and the resulting cash flow $\left[f_{i}\left(k_{i}\right)+k_{i} \nu\right] \cdot(1-\nu)^{t-1}$ for $0<t \leq \infty$. $\nu$ denotes the economic depreciation rate and $f_{i}\left(k_{i}\right)$ the pre-tax return on capital $k_{i}$. It is assumed that the rate of return $\frac{f_{i}\left(k_{i}\right)}{k_{i}}$ does not vary over time. Thus, the cash-flow $\left[f_{i}\left(k_{i}\right)+k_{i} \nu\right]$ decreases annually by a factor of $(1-\nu)$. Tax depreciation of investment in time $t>1$ amounts to $k_{i} \cdot\left[\alpha_{i} \cdot\left(1-\alpha_{i}\right)^{t-1}\right]$, where $\alpha_{i}$ denotes the tax depreciation rate.

We consider the case of a multinational consisting of a parent and a subsidiary. The parent 
is located in country 1 and the subsidiary is located in country 2 . The net present value (NPV) of multinational investment in both locations can be defined as

$$
N P V=\frac{\left(1-\tau_{1}\right)\left[f_{1}\left(k_{1}\right)+k_{1} \nu\right]}{\rho+\nu}+\frac{\tau_{1} \alpha_{1} k_{1}}{\rho+\alpha_{1}}+\frac{\left(1-\tau_{2}\right)\left[f_{2}\left(k_{2}\right)+k_{2} \nu\right]}{\rho+\nu}+\frac{\tau_{2} \alpha_{2} k_{2}}{\rho+\alpha_{2}} .
$$

The investor's discount rate is denoted by $\rho . \tau_{i}$ denotes the statutory tax rate at location $i$. The first and third part of (1) reflect the net present value of after-tax earnings generated in both locations. The second and fourth part of (1) represent the present value of tax savings due to the depreciation of the invested capital in both locations. Given the pre-tax cash flow, an investment's net present value depends on the relationship between the rate of economic depreciation and the rates of tax depreciation as well as on statutory tax rates.

We find the optimum investment level at location 2 which the company chooses by differentiating equation (1) with respect to its capital invested in location 2 :

$$
\frac{\partial N P V}{\partial k_{2}}=\left(1-\tau_{2}\right) \frac{\left[f_{2, k}\left(k_{2}\right)+\nu\right]}{\rho+\nu}+\frac{\tau_{2} \alpha_{2}}{\rho+\alpha_{2}} \equiv 0
$$

The optimum investment level depends on the statutory tax rate as well as the tax depreciation rate. The effects of a higher tax rate and a higher tax depreciation rate on the net present value are shown by the following simple comparative static properties. Assuming neoclassical properties, $f_{i, k}\left(k_{i}\right)>0, f_{i, k k}\left(k_{i}\right)<0$, where the rate of return decreases with increasing investment levels in $t=0$, and by using equation (2), we obtain the marginal effects in regard to investment by the tax rate as well as the tax depreciation rate:

$$
\begin{gathered}
\frac{d k_{2}}{d \tau_{2}}=\frac{1}{f_{2, k k}\left(k_{2}\right)\left(1-\tau_{2}\right)}\left[f_{2, k}\left(k_{2}\right)+\nu-\alpha_{2} \frac{\rho+\nu}{\rho+\alpha_{2}}\right] \gtrless 0, \\
\frac{d k_{2}}{d \alpha_{2}}=-\frac{1}{f_{2, k k}\left(k_{2}\right)\left(1-\tau_{2}\right)} \cdot \frac{\tau_{2}(\rho+\nu) \rho}{\left(\rho+\alpha_{2}\right)^{2}}>0 .
\end{gathered}
$$

A higher statutory tax rate depresses investment, if the tax depreciation rate does not 
largely exceed the economic depreciation rate. However, a higher tax depreciation rate constitutes an investment incentive. Given a higher tax depreciation rate in location 2 than in location $1\left(\alpha_{2}>\alpha_{1}\right)$, the parent may prefer to shift investments to location 2 . The investment incentive of the tax depreciation rate increases with a higher statutory tax rate.

Let us now compare these cash-flow based tax incentives with informations provided by financial accounting. IAS 12.86 defines tax expenses for financial accounting purposes as the sum of both current and deferred taxes. A deferred tax liability (tax asset) shall be recognised for taxable (deductible) temporary differences (IAS 12.15, IAS 12.24). Deferred tax liabilities arise if the carrying amount of an asset exceeds the asset's tax base. When the company recovers the carrying amount, it realises a taxable profit (the difference between the carrying amount and the asset's tax base) and pays corporate income taxes. Therefore, the company recognises a deferred tax liability, which represents future income tax payments. According to IAS 12.85, the company shall use a tax rate that provides the most meaningful information to users of financial statements. For a company operating in several countries, IAS 12.85 recommends the use of the domestic tax rate in each individual country.

According to the IFRS Framework, accrual accounting provides the type of information "...that is most useful to users in making economic decisions"(Framework, 22). Consequently, shareholders should be able to assess the value of the company's investments, when after-tax profits serve as a proxy for the company's net cash-flow. In the context of the model, the deferred taxes in time $t>1$ are defined as the difference of accounting depreciation (which equals the economic depreciation) and tax depreciation in a location multiplied by the respective statutory tax rate: $\tau_{i} \cdot\left[\nu \cdot(1-\nu)^{t-1}-\alpha_{i} \cdot\left(1-\alpha_{i}\right)^{t-1}\right]$. After inserting this into equation (1) the investment's net present value adjusted for deferred taxes $\left(\mathrm{NPV}_{D}\right)$ equals 


$$
\begin{aligned}
N P V_{D} & =\frac{\left(1-\tau_{1}\right)\left[f_{1}\left(k_{1}\right)+k_{1} \nu\right]}{\rho+\nu}+\frac{\tau_{1} \alpha_{1} k_{1}}{\rho+\alpha_{1}}-\frac{\tau_{1} \alpha_{1} k_{1}}{\rho+\alpha_{1}}+\frac{\tau_{1} k_{1} \nu}{\rho+\nu} \\
& +\frac{\left(1-\tau_{2}\right)\left[f_{2}\left(k_{2}\right)+k_{2} \nu\right]}{\rho+\nu}+\frac{\tau_{2} \alpha_{2} k_{2}}{\rho+\alpha_{2}}-\frac{\tau_{2} \alpha_{2} k_{2}}{\rho+\alpha_{2}}+\frac{\tau_{2} k_{2} \nu}{\rho+\nu} \\
& =\frac{\left(1-\tau_{1}\right) f_{1}\left(k_{1}\right)+k_{1} \nu}{\rho+\nu}+\frac{\left(1-\tau_{2}\right) f_{2}\left(k_{2}\right)+k_{2} \nu}{\rho+\nu} .
\end{aligned}
$$

The information provided by financial accounting suggests that the tax expenses are determined in each period only by statutory tax rates in both locations. Timing effects resulting from tax depreciation rules vanish.

Since the profit-based net present value $N P V_{D}$ of equation (5) does not assess the true value of the company's investment, tax expenses reported by financial accounting do not correctly indicate the impact of taxes on investment decisions. Differentiating equation (5) with respect to the capital invested in location 2 leads to

$$
\frac{\partial N P V_{D}}{\partial k_{2}}=\left(1-\tau_{2}\right) f_{2, k}\left(k_{2}\right)+\nu \equiv 0
$$

The investment decision seems to only be affected by the statutory tax rate in location 2. However, discounting the accounting profit after taxes plus depreciation leads to the correct value of the company's investments $\left(\mathrm{NPV}=\mathrm{NPV}_{D}\right)$, only if the net present value of tax depreciation equals the net present value of economic depreciation $\left(\nu=\alpha_{i}\right)$. In this case, the first order conditions (2) and (6) are equal. Thus, the tax information provided by IAS 12 implies that tax depreciation rules are neutral with respect to investment decisions.

Since IAS 12 eliminates relevant information concerning timing differences between the locations' tax depreciation rules, reported tax expenses are misleading as a performance measure of tax planning. From an analytical point of view, neither company's tax management nor shareholders investment decisions should be based on accrual accounting information. However from an empirical point of view, it is unclear to what extent international 
investment decisions are driven by tax depreciation incentives. Hence, the tax information provided by financial accounts might not be completely misleading.

\subsection{International Tax Planning and Profit Shifting}

Profit shifting is possible by means of intrafirm financing decisions or intrafirm transfer pricing. Therefore, tax savings resulting from profit shifting are a function of the share of intrafirm debt, $\mu_{i}$, and of the volume of intrafirm trading, $\omega_{i}$. Subsidiaries are subject to corporate income tax in the country of their legal domicile. Under an exemption system, as it is in force in Germany and in most other European countries, ${ }^{1}$ repatriated profits are not taxed. ${ }^{2}$ Hence, the term $S_{i}\left(\mu_{i}, \omega_{i}\right) \cdot\left(\tau_{i}-\tau_{j}\right)$ denotes tax savings arising from the shifting of the profit amount $S_{i}\left(\mu_{i}, \omega_{i}\right)$ from location $i$ to location $j$. The function $c_{i}\left(\mu_{i}, \omega_{i}\right)$ represents non-tax costs of profit shifting; $c_{i}\left(\mu_{i}, \omega_{i}\right)$ is a convex function, i.e. $c_{i, \mu}\left(\mu_{i}, \omega_{i}\right)>0$, $c_{i, \mu \mu}\left(\mu_{i}, \omega_{i}\right)>0$ as well as $c_{i, \omega}\left(\mu_{i}, \omega_{i}\right)>0$ and $c_{i, \omega \omega}\left(\mu_{i}, \omega_{i}\right)>0$. In context of the model developed in section 2.1, we can write the net present value of investments at two locations in presence of profit shifting. When considering the opportunity to shift profits between jurisdictions, we obtain the investments' cash flow-based net present value

$$
\begin{aligned}
N P V= & \frac{\left(1-\tau_{1}\right)\left[f_{1}\left(k_{1}\right)+k_{1} \nu\right]}{\rho+\nu}+\frac{\tau_{1} \alpha_{1} k_{1}}{\rho+\alpha_{1}}+\frac{S_{1}\left(\mu_{1}, \omega_{1}\right)\left(\tau_{1}-\tau_{2}\right)-c_{1}\left(\mu_{1}, \omega_{1}\right)\left(1-\tau_{1}\right)}{\rho+\nu} \\
& +\frac{\left(1-\tau_{2}\right)\left[f_{2}\left(k_{2}\right)+k_{2} \nu\right]}{\rho+\nu}+\frac{\tau_{2} \alpha_{2} k_{2}}{\rho+\alpha_{2}}+\frac{S_{2}\left(\mu_{2}, \omega_{2}\right)\left(\tau_{2}-\tau_{1}\right)-c_{2}\left(\mu_{2}, \omega_{2}\right)\left(1-\tau_{2}\right)}{\rho+\nu} .
\end{aligned}
$$

Again, introducing deferred taxes eliminates the timing effects of tax depreciation, as it is demonstrated in section 2.1. In this case we obtain the profit-based net present value,

\footnotetext{
${ }^{1}$ We neglect the taxes levied on a small part of repatriated profits. Germany taxes $5 \%$ of the respective profits.

${ }^{2}$ Note that even in countries employing a credit system, such as in Great Britain or in the US, companies seem to avoid repatriation taxes (Altshuler and Grubert, 2003).
} 


$$
\begin{aligned}
N P V_{D} & =\frac{\left(1-\tau_{1}\right) f_{1}\left(k_{1}\right)+k_{1} \nu}{\rho+\nu}+\frac{S_{1}\left(\mu_{1}, \omega_{1}\right)\left(\tau_{1}-\tau_{2}\right)-c_{1}\left(\mu_{1}, \omega_{1}\right)\left(1-\tau_{1}\right)}{\rho+\nu} \\
& +\frac{\left(1-\tau_{2}\right) f_{2}\left(k_{2}\right)+k_{2} \nu}{\rho+\nu}+\frac{S_{2}\left(\mu_{2}, \omega_{2}\right)\left(\tau_{2}-\tau_{1}\right)-c_{2}\left(\mu_{2}, \omega_{2}\right)\left(1-\tau_{2}\right)}{\rho+\nu} .
\end{aligned}
$$

Using equation (7) and (8), respectively, and considering the optimal profit shifting volumes, tax planning incentives can be described. Let us, for example, focus on subsidiary 2. For the optimum of profit-shifting activities, we obtain the first-order conditions

$$
\begin{aligned}
& \frac{\partial N P V}{\partial \mu_{2}}=\frac{\partial N P V_{D}}{\partial \mu_{2}}=S_{2, \mu}\left(\mu_{2}, \omega_{2}\right)\left(\tau_{2}-\tau_{1}\right)-c_{2, \mu}\left(\mu_{2}, \omega_{2}\right)\left(1-\tau_{2}\right) \equiv 0, \\
& \frac{\partial N P V}{\partial \omega_{2}}=\frac{\partial N P V_{D}}{\partial \omega_{2}}=S_{2, \omega}\left(\mu_{2}, \omega_{2}\right)\left(\tau_{2}-\tau_{1}\right)-c_{2, \omega}\left(\mu_{2}, \omega_{2}\right)\left(1-\tau_{2}\right) \equiv 0 .
\end{aligned}
$$

The first-order conditions are only influenced by statutory tax rates. Both first-order conditions on the basis of after-tax cash flows and based on after-tax profits are the same. Therefore, it is evident that the profit shifting effect on tax payments is outlined by reported tax expenses within the company's financial accounting.

The tax incentive to use intrafirm trading as well as internal debt becomes clearer, when comparative static properties are employed. It is a reasonable assumption that the marginal effect of intrafirm trading or internal debt is constant with increasing intrafirm trading or internal debt, i.e. $S_{2, \mu \mu}\left(\mu_{2}, \omega_{2}\right)=0$ and $S_{2, \omega \omega}\left(\mu_{2}, \omega_{2}\right)=0$. Moreover, we assume that $\mu$ and $\omega$ can be used independently, i.e. the cross derivatives $c_{2, \mu \omega}\left(\mu_{2}, \omega_{2}\right)=0$ and $S_{2, \mu \omega}\left(\mu_{2}, \omega_{2}\right)=0$. Then, using equations (9) and (10), respectively, we obtain for the comparative static effects

$$
\frac{d \mu_{2}}{d \tau_{2}}=\frac{S_{2, \mu}\left(\mu_{2}, \omega_{2}\right)+c_{2, \mu}\left(\mu_{2}, \omega_{2}\right)}{\left(1-\tau_{2}\right) c_{2, \mu \mu}\left(\mu_{2}, \omega_{2}\right)}>0
$$




$$
\frac{d \omega_{2}}{d \tau_{2}}=\frac{S_{2, \omega}\left(\mu_{2}, \omega_{2}\right)+c_{2, \omega}\left(\mu_{2}, \omega_{2}\right)}{\left(1-\tau_{2}\right) c_{2, \omega \omega}\left(\mu_{2}, \omega_{2}\right)}>0
$$

The size of internal debt as well as of intrafirm trading is positively affected by an increasing local tax rate: A rising local tax rate generates increasing incentives to create tax deductions, in the respective location, by means of interest payments for intrafirm debt or by means of higher payments for intrafirm trading.

Since this type of tax planning is well documented by reported tax expenses, according to IAS 12 , the information provided by financial accounting is useful to assess a multinational company's tax planning performance by means of profit shifting. The more a multinational company engages in profit shifting and the higher its profits are, the more the statutory tax rate dominates the company's tax planning activities and the less important is the net present value of tax depreciation savings for investment decisions. Thus, the reported tax expenses of a multinational company may not be seriously misleading.

From an analytical point of view, it is unclear if profit shifting dominates investment shifting. As it is demonstrated in section 2.1, high statutory tax rates may deter investments from a location, even if the locations' tax depreciation rate exceeds the economic depreciation rate. However, if profits can be shifted away from the high tax location, the tax depreciation rate becomes more relevant for real investment decisions. We may then find investments in high tax locations that provide favourable tax depreciation rules, whereas a significant part of investment profits are taxed in low tax locations. However, considering anti-avoidance tax legislation and non-tax constraints of profit shifting, it is unclear whether and to what extent profit shifting works effectively in practice. Therefore, the following empirical analysis on tax planning behaviour of German multinationals is carried out to provide insights into the practical relevance of both investment shifting and profit shifting as tax planning tools. Note that we do not focus on the relationship between reported income taxes and share prices but on the companies' tax planning behaviour. 


\section{Investigation Approach}

The practical relevance of different tax planning tools presented above is empirically analysed using data at the affiliate's level. For the empirical analysis the Micro-database Direct investment, $M i D i$, provided by the Deutsche Bundesbank, is used. ${ }^{3}$ This database contains financial statements of German outbound and inbound FDI as well as some additional information on the parent company.

With regard to tax planning by means of profit shifting between jurisdictions, the comparative static analysis provides testable relationships between company taxation and intrafirm trading as well as intrafirm financing. The first implication, testing the existence of tax planning via finance, can be concluded from equation (11), which suggests a positive effect of a higher tax rate, at the affiliate's location, on using company-internal debt. A simple estimation equation for the share of intrafirm leverage $I C L$ in country $i$ taken by company $k$ in period $t$ could be

$$
I C L_{k, i, t}=a_{0}+a_{1} \tau_{i}+a_{2} \ln \left(\text { LendingRate } e_{i, t}\right)+a_{k}+a_{t}+\epsilon_{k, i, t},
$$

where $a_{t}$ denotes a time effect and $a_{k}$ a company fixed effect. ${ }^{4}$

With regard to profit shifting by pricing of intrafirm sales, equation (12) suggests that intrafirm sales decreases with an increasing local tax rate. The MiDi data-set used for the empirical analysis does not contain direct information on intrafirm sales of German FDI. However, the balance sheet item 'accounts receivable from affiliated companies' can be used instead. This item, denoted by $A R$, constitutes a snapshot of the annual intrafirm sales, i.e. the unpaid share of intrafirm sales at the balance sheet date. The relationship between intrafirm sales and its unpaid share at the balance sheet date, the 'accounts receivable from

\footnotetext{
${ }^{3}$ See Lipponer (2006) for a detailed description of the data set.

${ }^{4}$ See Desai, Foley and Hines (2004) as well as Buettner, Overesch, Schreiber and Wamser (2006) for a detailed description of empirical approaches to test tax incentives on financial structure choices.
} 
affiliates', depends on local costs of refinancing outstanding bills as well as on firm specifics, like a specific cash management system. A country specific lending rate constitutes a good proxy for local refinancing costs, whereas company specifics are controlled by a company effect $b_{k}$. However, it should be mentioned that the payment date of accounts receivable is irrelevant for tax purposes, as profits or losses are entered at the delivery date and not at the payment date.

Then, the following estimation equation can be used,

$$
\begin{aligned}
\ln \left(A R_{k, i, l, t}\right) & =b_{0}+b_{1} \tau_{i, t}+b_{2} x_{i, t}+b_{3} \ln \left(\text { LendingRate }_{i, t}\right) \\
& +b_{k}+b_{t}+b_{l}+\epsilon_{k, i, l, t},
\end{aligned}
$$

where $b_{k}$ denotes a firm effect, $b_{l}$ an industry effect and $b_{t}$ a time specific effect. ${ }^{5}$ Intrafirm sales also depend on economic factors, as sales are based on delivered goods and services. Therefore, company and industry effects are considered to control for unobservable heterogeneity between different company groups and industries. Moreover, the vector $x_{i}$ contains a set of control variables.

Finally, we consider tax planning with regard to real investment decisions. As it is demonstrated in section 2.1, reported tax expenses can be misleading if a company's tax planning activities are focused on timing effects of taxation, due to various tax depreciation rules. Therefore, the main point of interest is whether tax incentives, due to different tax depreciation allowances, have an impact on tax planning activities.

With regard to tax effects on real investment decisions within existing company structures, the following estimation equation is used. This approach, which is similar to Buettner and Wamser (2006), is likely to test the tax response of the investment level at each affiliate of

\footnotetext{
${ }^{5}$ Similar investigation approaches, which are focused on intrafirm sales, are used by Grubert (2003) as well as Clausing (2006).
} 
the firm $k$,

$$
\ln \left(\text { FixedAssets } s_{k, i, t}\right)=c_{0}+c_{1} \tau_{i, t}+c_{2}\left(P V D_{i, t} \times \tau_{i, t}\right)+c_{3} z_{i, t}+c_{k}+c_{t}+\epsilon_{k, i, t},
$$

where the present value of depreciation at location $i$ is denoted by $P V D_{i}$, while $z_{i}$ denotes a vector of control variables.

\section{Data}

The MiDi database provides information on the investment object's unconsolidated balance sheet including further information on the type of investment and on the investor. This analysis is based on data of German outbound FDI positions. A favourable characteristic of the data set is the possibility to trace direct investment positions of individual firms over time. The version used provides firm-level panel data for the period of 1996 to 2003 . The collection of the data is enforced by German law, which requires reporting obligations for certain international transactions and positions. ${ }^{6}$ With regard to outbound FDI, each German enterprise has to report its holdings of foreign assets. The database comprises direct FDI and indirect FDI positions, if holdings are above some threshold level. ${ }^{7}$ However, for the foreign object a time-constant threshold level of a balance sheet total above 3 million euro is applied. Therefore any problems which may arise from different threshold levels are avoided.

As financial statements based on IFRS must be prepared by public companies, only balance sheet data of German parent companies are considered, which are in the legal form of a public limited company (Aktiengesellschaft). As full consolidation is only applied if affiliates are controlled, only observations are kept that display a participation level of

\footnotetext{
${ }^{6}$ Sec. 26 Aussenwirtschaftsgesetz (Law on Foreign Trade and Payments) in connection with Aussenwirtschaftsverordnung (Foreign Trade and Payment Regulations).

${ }^{7}$ For details about the threshold levels see Lipponer (2006).
} 
the German parent company of more than 50\%. Furthermore, only firm observations are included which display positive real capital and turnover for every reported year. All companies in the sample, which actually produce at home and abroad, are considered, i.e. holdings and financial service providers are excluded. As the model deals with a simple two-tier company structure, indirectly held investments are excluded. Table 1 presents the spatial apportionment of the considered German controlled affiliates from 1996 until 2003.

Table 1: Considered balance sheet accounts of German FDI 1996 -2003

\begin{tabular}{l|rrrr}
\hline \hline Destination Country & Subsidiaries & $\begin{array}{r}\text { Assets }(€ 1000) \\
\text { per subsidiary }\end{array}$ & $\begin{array}{r}\text { Share } \\
\text { Assets }\end{array}$ & $\begin{array}{r}\text { Sales } \\
\text { per subsidiary }\end{array}$ \\
\hline Australia & & & & \\
Austria & 367 & 6,708 & .014 & 38,017 \\
Belgium & 657 & 16,137 & .059 & 77,438 \\
Canada & 473 & 17,461 & .046 & 95,116 \\
Czech Republic & 215 & 21,563 & .026 & 84,698 \\
Denmark & 578 & 32,811 & .105 & 88,154 \\
Finland & 219 & 12,018 & .015 & 53,881 \\
France & 96 & 6,597 & .003 & 38,594 \\
Great Britain & 1,178 & 8,572 & .056 & 89,688 \\
Greece & 852 & 6,992 & .033 & 91,162 \\
Hungary & 154 & 5,132 & .004 & 35,234 \\
Ireland & 351 & 24,515 & .048 & 94,006 \\
Italy & 79 & 15,147 & .007 & 40,620 \\
Japan & 1,004 & 8,590 & .048 & 50,866 \\
Luxembourg & 373 & 16,866 & .035 & 122,400 \\
Netherlands & 15 & 6,108 & .001 & 66,400 \\
Norway & 572 & 7,748 & .024 & 45,479 \\
Poland & 121 & 7,260 & .005 & 42,463 \\
Portugal & 571 & 10,361 & .033 & 52,149 \\
Slovakia & 122 & 10,345 & .007 & 42,287 \\
Spain & 78 & 41,996 & .018 & 55,795 \\
Sweden & 679 & 10,890 & .041 & 54,239 \\
Switzerland & 296 & 11,702 & .019 & 43,017 \\
USA & 676 & 6,263 & .023 & 63,916 \\
\hline Total & 960 & 62,934 & .334 & 170,433 \\
\hline & 10,686 & 16,948 & 1.0 & 78,980 \\
\hline
\end{tabular}

According to equations (13) and (14) financial ratios as well as the natural log of 'accounts 
receivable from affiliated companies' are taken from the MiDi database as dependent variables. Additionally, for estimating (15) the natural log of reported fixed assets is used as the dependent variable. Moreover, the natural log of total sales of each firm is also taken from the MiDi database.

Statutory tax rates are captured by the variable STR. In case of pure profit shifting by means of finance or transfer pricing, the statutory tax rate represents tax savings due to one unit shifted profit. ${ }^{8}$ The tax rate does not indicate tax savings by profit shifting if an affiliate exhibits a loss carry forward or a current loss for tax purposes. For this reason the dummy variable DLCF is used as an indicator for the possibility to offset former losses with actual profits taking on the value one, while otherwise zero. As unpaid dividends and interest of financial assets may cause higher accounts receivable, a dummy variable DFIN is used, which represents financial interests in affiliated companies having the value one, while otherwise zero. Furthermore, an indicator for the present value of depreciation for tax purposes (PVD) of machinery is taken into account along with statutory tax rates. This PVD indicator is calculated according to the European Commission (2001) using a nominal interest rate of 7.1 per cent.

Additionally, country specific control variables are used. First, as the data does not contain any information about firm-specific interest expenses, country specific lending rates for credits to the private sector are taken, which are provided by the IMF International Financial Yearbook and augmented by data provided by the European Central Bank. These are used as a proxy of refinancing costs. Furthermore, nominal GDP is taken from the OECD. In addition, flight distance between the affiliate location and Germany, as well as hourly workers compensation, are used. Finally, a corruption perception index is taken from Transparency International as corruption may deter FDI (e.g. Wei, 2002).

\footnotetext{
${ }^{8}$ For analysing the tax incentive on capital structure, the statutory tax rate is modified by applicable restrictions on interest deductions. For instance, in Italy interest expenses are not deductible from local business tax (IRAP).
} 
Table 2: Descriptive Statistics

\begin{tabular}{|c|c|c|c|c|c|}
\hline Variable & Definition & Mean & Std.Dev. & Min. & Max. \\
\hline \multicolumn{6}{|c|}{ Firm level variables } \\
\hline $\mathrm{AR}^{a)}$ & $\begin{array}{l}\text { intra-company accounts } \\
\text { receivable in } € \text { thousand }\end{array}$ & 7,946 & 55,886 & 1 & $3,369,289$ \\
\hline $\operatorname{DFIN}^{a)}$ & binary & .321 & .467 & 0 & 1 \\
\hline DLCF & binary & .308 & .462 & 0 & 1 \\
\hline Equity & share of equity & .389 & .239 & .001 & .999 \\
\hline Fixed Assets & fixed assets stock in $€$ thousand & 16,948 & 188,831 & 1 & $14,400,000$ \\
\hline Sales & sales in $€$ thousand & 78,980 & 591,588 & 1,000 & $51,900,000$ \\
\hline ICL & share of intra-company leverage & .290 & .245 & .001 & .998 \\
\hline \multicolumn{6}{|c|}{ Tax variables } \\
\hline PVD & pres. val. of depreciation allow. & .773 & .105 & .332 & .914 \\
\hline PVD x STR & & .272 & .066 & .077 & .428 \\
\hline STR & statutory profit tax rate & .351 & .069 & .100 & .532 \\
\hline \multicolumn{6}{|c|}{ Further characteristics } \\
\hline Corruption & Corruption Perception Index & 6.96 & 1.71 & 3.42 & 10 \\
\hline Distance & flight distance in $\mathrm{km}$ & 2,168 & 3,508 & 190 & 16,470 \\
\hline GDP & in billion US dollars & 1,547 & 2,561 & 18.9 & 10,600 \\
\hline Labour Cost & in US dollars per hour & 16.6 & 6.42 & 2.79 & 32.18 \\
\hline Lending Rate & local lending rate & .073 & .040 & .018 & .273 \\
\hline
\end{tabular}

10,686 observations. ${ }^{a)}: 8,383$ observations

Table 2 presents descriptive statistics of the data used for the basic sample, including 10,686 balance sheets of German outbound investments during the period from 1996 until 2003.

\section{Empirical Results}

According to the investigation approach presented in section 3, we carry out three different sets of estimations. All analysis involves panel data regressions, which include company 
fixed effects to control for unobservable firm-specifics that may be correlated with explaining variables. Additionally, year dummies are considered to control for unobservable time effects. In order to control for reasonable heterogeneity between industries, dummies for 61 industries at the affiliate level are included.

Table 3: Taxation and Financial Structure Choice

\begin{tabular}{l|ccc|ccc}
\hline \hline \multirow{2}{*}{ Dependent Variable } & \multicolumn{3}{|c|}{ Share of Intrafirm Debt } & \multicolumn{3}{|c}{ Share of Equity } \\
& $(1)$ & $(2)$ & $(3)$ & $(4)$ & $(5)$ & $(6)$ \\
& & & & & & \\
\hline & & & & & & \\
STR & $.207^{*}$ & $.256^{*}$ & $.291^{*}$ & $-.449^{*}$ & $-.428^{*}$ & $-.450^{*}$ \\
$\ln ($ Lending Rate) & $(.057)$ & $(.060)$ & $(.064)$ & $(.058)$ & $(.057)$ & $(.064)$ \\
& $.047^{*}$ & $.041^{*}$ & $.037^{*}$ & -.004 & -.007 & -.005 \\
$\ln$ (Sales) & $.008)$ & $(.008)$ & $(.008)$ & $(.009)$ & $(.009)$ & $(.008)$ \\
& & $-.021^{*}$ & $.019^{*}$ & & $-.009^{*}$ & $-.011^{*}$ \\
STR x DLCF & & $(.003)$ & $(.003)$ & & $(.003)$ & $(.003)$ \\
& & & $-.230^{*}$ & & & $.175^{*}$ \\
DLCF & & & $(.089)$ & & & $(.094)$ \\
& & & $.145^{*}$ & & & $-.119^{*}$ \\
& & & $(.002)$ & & & $(.003)$ \\
$\mathrm{R}^{2}$ & .033 & .042 & .059 & .066 & .064 & .084 \\
\hline
\end{tabular}

Robust standard errors are in parentheses. A star denotes significance at the $5 \%$ level. All estimates include a full set of firm, industry and time dummies. 10,686 observations, 775 firms.

First, we focus on tax incentives to shift profits in the context of financing decisions. The regressions are based on equation (13). The results presented in table 3 indicate that taxes indeed determine capital structure choices of German multinationals. Specifications in columns (1)-(3) indicate a significant positive effect of a higher local tax rate on the share of internal debt. Furthermore, columns (4)-(6) show that the share of equity finance is reduced by an increasing statutory tax rate at the affiliate location. As interest deductions do not save taxes if affiliates carry forward any losses, affiliates which exhibit a loss carry forward constitute a suitable control group. This group is indicated by the dummy variable 
DLCF, which takes on the value one if an affiliate exhibits a loss carry forward, while otherwise zero. The existence of a loss carry forward has a positive basic effect on the use of internal debt as well, and, of course, a negative effect on the level of equity. However, the opposite coefficient of the interaction term between DLCF and the statutory tax rate supports the theory that taxes do not matter if an affiliate has a loss carry forward and cannot avoid additional taxes by additional interest deductions.

The local lending rate does not influence the share of equity used, and a higher local lending rate effects more internal debt. The latter effect is in line with existing empirical findings ${ }^{9}$, which clearly indicate that internal debt constitutes a substitute for external debt, when local costs of external borrowing increase. The substitution proposition is also supported by a negative effect of larger sales on internal debt share, as a larger sales size is associated with higher cash flows and, thus, might improve the access to external capital.

With regard to the magnitude of estimated tax effects, the results suggest that affiliates without loss carry forward have a 2.9 percentage point higher internal debt ratio and a 4.5 percentage point smaller equity ratio if the tax rate is increased by 10 percentage points. To sum up, our estimates support the theory that tax planning via finance works effectively in practice.

Second, the tax response of intrafirm sales is analysed. The specifications presented in table 4 are based on equation (14). As the dependent variable the natural log of 'accounts receivable from affiliated companies' is used. However, the explaining variable total turnover may be simultaneously determined together with the dependent variable. For this reason, all regressions are instrument variable (IV) estimations, where the natural log of GDP is used as an instrument for the variable $\ln$ (Sales). Typically, GDP indicates the size of the local market. Thus, the correlation between turnover and GDP is due to third-party sales. Intrafirm deliveries should not be affected by the size of the local market in which

\footnotetext{
${ }^{9}$ See Desai, Foley and Hines (2004) as well as Buettner, Overesch, Schreiber and Wamser (2006) for empirical evidence.
} 
Table 4: Taxation and Intrafirm Transfer Pricing

\begin{tabular}{l|cccc}
\hline \hline \multirow{2}{*}{ Dependent Variable } & \multicolumn{5}{|c}{ ln(Accounts Receivable from Affiliates) } \\
& $(1)$ & $(2)$ & $(3)$ & $(4)$ \\
\hline \multirow{3}{*}{ STR } & & & & \\
& -.365 & -1.02 & -1.23 & $-1.86^{*}$ \\
$\ln$ (Sales) & $(.629)$ & $(.596)$ & $(.673)$ & $(.655)$ \\
& $.481^{*}$ & $.405^{*}$ & $.521^{*}$ & $.439^{*}$ \\
$\ln ($ Lending Rate) & $(.155)$ & $(.145)$ & $(.146)$ & $(.137)$ \\
& $-.720^{*}$ & $-.640^{*}$ & $-.683^{*}$ & $-.612^{*}$ \\
STR x DFIN & $(.118)$ & $(.102)$ & $(.114)$ & $(.099)$ \\
& & $1.90^{*}$ & & $2.07^{*}$ \\
DFIN & & $(.816)$ & & $(.814)$ \\
& & .455 & & .360 \\
STR x DLCF & & $(.302)$ & & $(.300)$ \\
& & & $3.13^{*}$ & $2.88^{*}$ \\
DLCF & & & $(.925)$ & $(.876)$ \\
& & & $-1.36^{*}$ & $-1.22^{*}$ \\
& & & $(.323)$ & $(.303)$ \\
\hline $\mathrm{R}^{2}$ & & & & .133 \\
\hline
\end{tabular}

All regressions are instrument variable (IV) estimations, where the natural log of GDP is used as an instrument for $\ln$ (Sales). Second stage regression results are presented only. F-tests of the significance of the first stage specifications are all significant at $1 \%$ level. Robust standard errors are in parentheses. A star denotes significance at the $5 \%$ level. All estimates include a full set of firm, industry and time dummies. 8,383 observations, 561 firms. Estimations are based on a subsample consisting of all observations which exhibit positive accounts receivable from affiliated companies.

the affiliate is located. Therefore, it is reasonable to use GDP as a suitable instrument for 'sales'.

The specification in column (4) presented in table 4 indicates a significantly negative effect of a higher local tax rate on 'accounts receivable from affiliated companies'. As accounts receivable constitute a snapshot of annual total sales, the result is likely to support a significantly negative impact of a higher tax rate on reported intrafirm sales. Similar to the set of results presented for finance responses to taxation, specifications are presented 
in columns (2)-(4) of table 4, which are likely to separate the tax effect on intrafirm sales more precisely. First, affiliates holding shares in other affiliated companies or giving loans to them may have higher 'accounts receivable from affiliated companies' at balance sheet date, resulting from unpaid dividends or interest. Therefore, a dummy variable, DFIN, which indicates that an affiliate has financial interests such as shareholding or giving credit in other affiliated companies, is included in the regressions presented in columns (2) and (4) of table 4. It is not surprising that the coefficients of the interaction between DFIN and the tax rate indicate less tax response of 'accounts receivable from affiliated companies' for these affiliates. Second, the dummy variable DLCF, which indicates the existence of a loss carry forward, is also used. The empirical results provided by columns (3) and (4) confirm that the existence of a loss carry forward effects an opposite tax impact on reported 'accounts receivable from affiliated companies'. This opposite effect is caused by the incentive to shift profits to an affiliate, which can offset additional profits with former losses. These results are in line with MacKie-Mason (1990), who finds significantly less response to tax by means of financing for US firms that suffer losses.

With regard to control variables, higher total turnover is associated with higher accounts receivable and a higher lending rate with smaller accounts receivable. The latter confirms the proposition that local costs of refinancing impact the company's internal payment policy. Intrafirm accounts receivable should be paid faster than higher local refinancing costs are.

According to equation (14), the coefficient of the tax rate must be interpreted as a semielasticity. Considering for example column (4), a one percentage point higher local tax rate is associated with 1.86 per cent smaller accounts receivable from affiliated companies in cases of German controlled companies, which do not have any loss carry forward or financial interest in affiliated companies. Furthermore, if a loss carry forward exists, a one percentage point higher tax rate attracts around 1 per cent higher accounts receivable. Although it is not possible to isolate a pricing effect from a quantity effect, we can clearly 
derive from the empirical results that profit shifting, due to intrafirm transfer pricing, works effectively in practice.

Table 5: Taxation and Investment

\begin{tabular}{l|cccc}
\hline \hline \multirow{2}{*}{ Dependent Variable } & \multicolumn{4}{|c}{$\ln ($ Fixed Assets) } \\
& $(1)$ & $(2)$ & $(3)$ & $(4)$ \\
\hline \multirow{3}{*}{ STR } & & & & \\
& $-1.10^{*}$ & $-1.08^{*}$ & $-1.43^{*}$ & $-1.58^{*}$ \\
PVD x STR & $(.400)$ & $(.424)$ & $(.345)$ & $(.345)$ \\
& $.796^{*}$ & $.793^{*}$ & $1.13^{*}$ & $1.16^{*}$ \\
STR x DLCF & $(.381)$ & $(.380)$ & $(.296)$ & $(.300)$ \\
& & -.067 & & .499 \\
DLCF & & $(.623)$ & & $(.459)$ \\
& & .009 & & -.031 \\
$\ln ($ Sales $)$ & & $(.220)$ & & $(.167)$ \\
$\ln ($ Lending Rate $)$ & & & $.759^{*}$ & $.767^{*}$ \\
& & & $(.021)$ & $(.021)$ \\
$\ln ($ GDP $)$ & .025 & .025 & .061 & .057 \\
& $(.050)$ & $(.050)$ & $(.038)$ & $(.039)$ \\
$\ln ($ Labour Cost $)$ & $.242^{*}$ & $.243^{*}$ & .025 & .016 \\
& $(.027)$ & $(.026)$ & $(.020)$ & $(.020)$ \\
$\ln$ (Distance) & -.100 & -.101 & $-.248^{*}$ & $-.241^{*}$ \\
& $(.053)$ & $(.052)$ & $(.041)$ & $(.041)$ \\
$\ln$ (Corruption) & -.014 & -.014 & $.048^{*}$ & $.045^{*}$ \\
& $(.018)$ & $(.018)$ & $(.014)$ & $(.015)$ \\
\hline $\mathrm{R}^{2}$ & $.342^{*}$ & $.343^{*}$ & $.209^{*}$ & $.202^{*}$ \\
& $(.094)$ & $. .095)$ & $(.075)$ & $(.075)$ \\
\hline
\end{tabular}

Robust standard errors are in parentheses. A star denotes significance at the $5 \%$ level. All estimates include a full set of firm, industry and time dummies. 10,686 observations, 775 firms.

Finally, real investment decisions are regarded and regressions are carried out according to equation (15). The results presented in table 5 support the expected negative impact on the size of investment in assets due to higher local tax rates. The specification also confirms a positive effect of a higher present value of tax depreciation on investment. The latter finding supports the proposition that tax planning is also focused on timing effects of taxation besides considering tax rate differences. 
With regard to control variables, we will shortly summarise some issues. The size of GDP, as an indicator for the market size, is associated with higher investment. Furthermore, higher labour costs are associated with less investment, and higher corruption effects smaller investment. The effect of distance is ambiguous. The positive effect of a higher local lending rate on investment size might be surprising. We know from results presented in table 3 concerning capital structure choices that German multinationals have some advantage against local firms, due to substitution opportunities of local debt by intrafirm debt. This indicates that there is a positive effect of higher local lending rates on investment, which may induce German multinationals to invest more in countries with less favourable capital market conditions due to a financing advantage. Furthermore, the specifications in columns (3) and (4) support the idea that the effect of the market size on investment is more precisely controlled by including the local sales size instead of a GDP proxy.

To sum up, our empirical results support clearly the suggestion that multinationals engage in profit shifting via debt financing and intra-firm sales. The theoretical analysis carried out in section 2.2 indicates that IAS 12 income tax reporting provides clear-cut information about international tax rate arbitrage, i.e. profit shifting. Thus, we conclude that insofar IAS 12 discloses the relevant information concerning the tax burden of a multinational company. However, we also find empirical evidence that multinationals engage in real investment shifting and that investment decisions are driven by both tax rates and tax depreciation rules. In section 2.1 we show that IAS 12 does not provide reliable information concerning tax consequences of real investment shifting. Thus, given the observable tax planning patterns of multinationals, we cannot rule out the possibility that IAS 12 income tax reporting might be misleading. 


\section{Conclusion}

IAS 12 (Income taxes) is designed to provide information about both the company's tax burden and tax planning performance. A multinational company may engage in international profit shifting as well as international investment shifting. Theoretical analysis indicates that IAS 12 does not provide reliable information about the tax consequences of international investment shifting because information concerning the timing effects of tax depreciation rules is suppressed. On the other hand, theoretical analysis shows that IAS 12 reveals the tax consequences of international profit shifting, which is only driven by differences in the country-specific statutory tax rates. Consequently, the information content of income tax accounting according to IAS 12 depends on the relevance of the respective type of tax planning in which the company engages.

Using firm-level data provided by the Deutsche Bundesbank, we find empirical evidence that German multinationals engage in tax driven international profit shifting via debt financing and intra-firm sales. However, we also find empirical evidence that tax induced investment shifting is relevant in practice. Therefore, we conclude that IAS 12 income tax accounting does not fully disclose the company's tax burden and tax planning performance.

Accounting information concerning income taxes may be used as a performance measure for a company's tax management if the focus of tax management is clearly on international profit shifting. When, however, the company's tax planning strategy is unclear shareholders should use accounting information provided by IAS 12 with caution, as both reported income taxes and reported effective tax rates might be seriously misleading. Of course, IAS 12 could be amended in order to provide better information about the tax consequences of international investment. However, it might be difficult to assess if better information due to full disclosure of tax effects on reported profits justifies both the increasing complexity and the additional costs of preparing financial statements. 


\section{Datasources and Definitions}

Firm-level data are taken from the MiDi-dataset of the Deutsche Bundesbank, see Lipponer (2006) for an overview.

Corporation tax data are taken from the IBFD databases and from tax surveys provided by the tax advisory companies Ernst\&Young, PwC and KPMG.

Distance is taken from "www.etn.nl/distance.htm". It contains flight distance in km.

GDP in US dollars, nominal, taken from OECD Economic Outlook (2005) 77.

Labour Cost are hourly compensation costs in US dollars for production workers in manufacturing. Source: U.S. Bureau of Labor Statistics, augmented by data provided by Eurostat as "Hourly Labor Costs" on an annual basis.

Lending Rate is the lending rate for credits to the private sector, taken from the IMF International Financial Yearbook (2005), augmented with corresponding ECB figures, that are taken from "www.ecb.int/stats/pdf/money/interest/rir_nrir.pdf".

Corruption is an index published annually by Transparency International ranking countries in terms of perceived levels of corruption as determined by expert assessments and opinion surveys. The scores used ranges from 10 (country perceived as virtually corruption free), to 0 (country perceived as almost totally corrupt).

\section{References}

Altshuler, R. and H. Grubert (2003), Repatriation taxes, repatriation strategies and multinational financial policy, Journal of Public Economics 87, 73 - 107.

Amir, E., M. Kirschenheiter and K. Willard (1997), The valuation of deferred taxes, 
Contemporary Accounting Research 14, 597-622.

Barth, M.E., W.H. Beaver and W.R. Landsmann (2001), The relevance of the value relevance literature for financial accounting standard setting: Another view, Journal of Accounting and Economics 31, 77-104.

Beaver, W.H. and R.E. Dukes (1972), Interperiod tax allocation, earnings expectations and the behavior of security prices, The Accounting Review 47, 320-332.

Becker, J., C. Fuest and C. Spengel (2006), Konzernsteuerquote und Investitionsverhalten, Zeitschrift fuer betriebswirtschaftliche Forschung 58, 730-742.

Bolton, C., A. Chastel and T. Young (2004), PricewaterhouseCoopers Global Retail \& Consumer Tax Benchmarking Survey - 2004, London.

Buettner, T., M. Overesch, U. Schreiber and G. Wamser (2006), Taxation and the choice of capital structure - Evidence from a panel of German multinationals, ZEW-Discussion Paper 06-067.

Buettner, T. and G. Wamser (2006), The impact of non-profit taxes on foreign direct investment: Evidence from German multinationals, Working Paper, Munich. Paper presented at the European Tax Policy Forum Conference 'The impact of corporation taxes across borders', London.

Chaney, P.K. and D.C. Jeter (1994), The effect of deferred taxes on security prices, Journal of Accounting, Auditing and Finance 9, 41-60.

Clausing, K.A. (2006), International tax avoidance and U.S. international trade, National Tax Journal 59, 269-287.

Desai, M.A., C.F. Foley and J.R. Hines (2004), A multinational perspective on capital structure choice and internal capital markets, The Journal of Finance 59, 2451-2487.

Devereux, M. and R. Griffith (1998), Taxes and the location of production - evidence from a panel of US multinationals, Journal of Public Economics 68, 335-367. 
European Commission (2001), Company taxation in the internal market, COM(2001)582 final, Luxembourg.

Givoly, D. and C. Hayn (1992), The valuation of the deferred tax liability: Evidence from the stock market, The Accounting Review 67, 394-410.

Guenther, D.A. and R.C. Sansing (2000), Valuation of the firm in the presence of temporary book-tax differences: The role of deferred tax assets and liabilities, The Accounting Review 75, 1-12.

Grubert, H. (2003), Intangible income, intercompany transactions, income shifting, and the choice of location, National Tax Journal 56, 221-242.

Halperin, R. and R. Sansing (2006), Is the effective tax rate an effective performance measure?, Working paper, Tuck School of Business at Dartmouth.

King, M. (1977), Public policy and the corporation, London.

King, M. and D. Fullerton (1984), The taxation of income from Capital, Chicago.

MacKie-Mason, J.K. (1990), Do taxes affect corporate financing decisions? The Journal of Finance 45, 1471-1493.

Lipponer, A. (2006), Microdatabase direct investment-MiDi. A brief guide, Bundesbank Working Paper, Frankfurt.

Scholes, M.S., M. Erickson, E.L. Maydew, T. Shevlin (2005), Taxes and business strategy - a planning approach, 3rd ed., Upper Saddle River.

Swenson, C. (1999), Increasing stock market value by reducing effective tax rates, Tax Notes , 1503-1505.

Wei, S.-J.(2002), How taxing is corruption on international investors? The Review of Economics and Statistics 82, 1-11. 